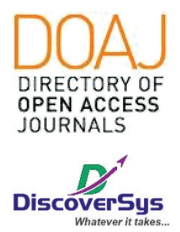

Published by DiscoverSys

\section{The compliance of hypertension patients in taking medication at Sukasada II Primary Health care from January - March 2016}

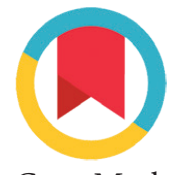

CrossMark

\author{
Shobana Ravendran, ${ }^{1 *}$ Komang Ayu Kartika Sari ${ }^{2}$
}

\section{ABSTRACT}

Background: Hypertension is a chronic disease where the adherence to therapy should be given serious attention. Compliance behavior is to obey the doctor's advice or procedure from the doctor about the use of drugs which had been prescribed by a consultation process between the patient and the patient's family physician. The health providers were influenced by two factors: behavioral and non-behavior factors which determined or shaped by three main factors such as predisposing factors, enabling factors, and reinforcing factors. The aim of this study to assess the compliances of taking medication in hypertensive patients at the Sukasada II Buleleng primary health care. Method: It was a quantitative descriptive study. The respondents were all hypertension patients who come to the Sukasada II primary health care from the period of January to March 2016. Data were obtained through interviews and questionnaires distributed to respondents who met the inclusion criteria and exclusion. The univariate and bivariate analysis was conducted in this study.

Results: The results of the research show the number of 84 sample contained 1 subjects with good adherence, 14 subjects with moderate adherence, and 69 subjects with less adherence. The cross tabulation showed that poor medication adherence in the elderly (90.9\%), followed by male gender (84.1\%), low education (82.7\%), higher knowledge (85.0\%), perception at close distance (85.7\%), travel time $\geq 15$ minutes (86.0\%), route conditions (84.1), do not have access difficulties (83.9), good family support (82.9), the low role of health care (100\%), and did not have any comorbidities (83.1\%).

Conclusion: The trend of hypertensive patients that are not taking medication mostly come from submissive to men, senior citizens, low educational level, and lesser role of healthcare personnel.

Keywords: Compliance, Medicine, Hypertension

Cite This Article: Ravendran, S., Sari, K.A.K. 2018. The compliance of hypertension patients in taking medication at Sukasada II Primary Health care from January - March 2016. Intisari Sains Medis 9(1): 52-58. D0I: 10.1556/ism.v9i1.156

\title{
ABSTRAK
}

Latar Belakang: Penyakit hipertensi merupakan penyakit kronis yang tidak dapat disembuhkan tetapi bisa dikendalikan, maka kepatuhan pada terapi harus diberi perhatian secara serius. Kepatuhan adalah perilaku untuk menaati saran -saran dokter atau prosedur dari dokter tentang penggunaan obat,yang telah didahului oleh proses konsultasi antara pasien atau keluarga pasien dengan dokter sebagai penyedia jasa. Menurut Green (1980), masalah kesehatan dipengaruhi oleh dua faktor yaitu faktor perilaku dan faktor non perilaku yang ditentukan atau terbentuk oleh tiga faktor utama yaitu, faktor predisposisi, faktor pendukung, dan faktor pendorong, dan faktor pendorong Tujuan penelitian ini untuk mengetahui kepatuhan minum obat pada pasien hipertensi di Puskesmas Sukasada II Kabupaten Buleleng.

Metode: Penelitian ini merupakan studi deskriptif kuantitatif. Respondennya adalah semua pasien hipertensi yang datang ke Puskesmas Sukasada II periode Januari - Maret 2016.Data diperoleh melalaui wawancara dan kuesioner yang disebar pada responden yang memenuhi kriteria inklusi dan eksklusi.Analisis data yang dilakukan berupa analisis univariat dan bivariate.

Hasil: Hasil penelitian menunjukkan dari 84 jumlah sampel penelitian terdapat 1 subyek dengan kepatuhan baik, 14 subyek dengan kepatuhan sedang, dan 69 subyek dengan kepatuhan kurang. Hasil tabulasi silang menunjukkan kepatuhan minum obat yang kurang berdasarkan umur paling banyak pada manula $(90,9 \%)$, jenis kelamin laki-laki (84.1\%),pendidikan rendah $(82,7 \%)$,pengetahuan tinggi $(85,0 \%)$,persepsi jarak dekat $(85,7 \%)$,waktu tempuh $\geq 15$ menit $(86,0 \%)$,kondisi jalan baik $(84,1)$,tidak mempunyai kesulitan akses $(83,9)$,dukungan keluarga baik $(82,9)$,peran petugas kesehatan rendah(100\%), dan tidak mempunyai penyakit penyerta (83.1\%).

Simpulan: Kecenderungan pasien hipertensi tidak patuh minum obat terbanyak pada laki-laki,berusia manula,dengan pendidikan yang rendah dan peran tugas kesehatan rendah.
Studi Pendidikan Dokter, Fakultas Kedokteran Universitas Udayana shoburaveendran@yahoo.com

Received: 2018-01-18 Accepted: 2018-01-27 Published: 2018-01-29
Kata Kunci: Kepatuhan, obat, hipertensi

Cite Pasal Ini: Ravendran, S., Sari, K.A.K. 2018. The compliance of hypertension patients in taking medication at Sukasada II Primary Health care from January - March 2016. Intisari Sains Medis 9(1): 52-58. D0I: 10.1556/ism.v9i1.156 


\section{INTRODUCTION}

Hypertension is a complex condition in which the blood pressure is settled above normal. The hypertension criteria used in the determination of case referred to the JNC VII diagnostic criteria 2003 , which is the measurement of systolic blood pressure $\geq 140 \mathrm{mmHg}$ or diastolic blood pressure $\geq 90 \mathrm{mmHg} .{ }^{1}$ Hypertension often does not cause symptoms so-called a silent killer, while persistent high blood pressure over a long period can lead to complications. Therefore, hypertension needs to be detected earlier with regular blood pressure measurement (blood pressure control). ${ }^{2}$

Hypertension or high blood pressure is a cardiovascular disease characterized by abnormal (increase) levels of systolic blood pressure $(\geq 140 \mathrm{mmHg})$ and diastolic $(\geq 90 \mathrm{mmHg})$ in patients. Based on the etiology, the hypertension is classified into primary (lifestyle and genetic) and secondary (constituted by certain diseases such as kidneys, heart, and endocrine disorders). The hypertension journals mention that primary hypertension as the most common cause of hypertension cases in adults accounted for $90-95 \%$, whereas secondary hypertension is about $2-10 \%$ of cases. ${ }^{3}$

According to the World Health Organization (WHO) 2007, hypertension contributes to nearly 9.4 million deaths from cardiovascular disease annually. It also increases the risk of coronary heart disease and stroke by $12 \%$ and $24 \%$ respectively. ${ }^{4}$ The Global Status Report Data of WHO on Non-Communicable Diseases 2010 shows that $40 \%$ of developing countries have hypertension, while developed countries only 35\%. In Southeast Asia, there are $36 \%$ of adults who suffer from hypertension and have killed 1.5 million people each year. The number of hypertensive patients will continue to rise sharply, predicted become $29 \%$ in 2025 or about 1.6 million adults suffer from hypertension worldwide. $^{2}$

Hypertension is a chronic disease that is not curable but can be controlled, then the adherence to therapy should be given serious attention. ${ }^{5}$ In addition to the adherence of hypertensive patients in taking medication on a regular basis, their willingness to see a doctor for control with a defined schedule should also be emphasized to ensure the success in controlling high blood pressure. So that the patient's active role and physician should cooperate in taking hypertensive medication. ${ }^{6}$

Adherence is a behavior to comply with a doctor's advice or procedures on drug use, which has been preceded by a consultation process between the patient or the patient's family with a physician as a health service provider. ${ }^{7}$ According to Green (1980), health problems are influenced by two factors: behavioral and nonbehavioral factors. ${ }^{8}$ The behavior itself is determined or formed by three main factors namely: predisposing factors, enabling factors, and reinforcing factors. ${ }^{9}$

Based on the profile data in 2015 at Sukasada II Public Health Center, Sukasada Sub-District, Buleleng District, hypertension ranks sixth from the top ten diseases with 755 cases. The initial surveys conducted in the Sukasada community showed that out of 10 hypertensive patients surveyed found that 6 patients were disobedient to take medication. In this regard, this study aims to describe the adherence of hypertensive patients receiving medicine at Sukasada II Public Health Center.

\section{METHODS}

This study was a descriptive study using cross-sectional design to determine the description of medication adherence in hypertensive patients at Sukasada II Public Health Center. Sampling and data processing was conducted in the working area of Sukasada II Public Health Center, Buleleng Regency of Bali Province from April to May 2016. Samples were obtained from all patients with hypertension who came to the Sukasada II Primary Health Care, Buleleng in the period of January-March 2016 which included 84 respondents. The inclusion criteria were patients with a history of at least 1-year hypertension who visited the Sukasada II Public Health Center more than once based on the register and willing to participate in the study. The Modified Morisky Adherence Scale (MMAS-8) questionnaire was carried out to measure adherence with hypertensive drug preparation, as well as other questionnaires in obtaining information from self-data and description of factors related to treatment adherence. Data analysis was done by using univariate and bivariate test.

\section{RESULTS}

\section{Subject Characteristics}

From 84 sample sizes, there was 1 subject with good adherence, 14 subjects with moderate adherence, and 69 subjects with poor adherence. The subject characteristics are divided into the sociodemographic level, medication adherence level, knowledge level, house distance, travel time, route conditions, access difficulties, family support, health staff role, as well as any comorbidities. The univariate results can be seen in Table 1 and 2 .

In Table 1 , it can be seen that most of the respondents were male (52.4\%), followed by early age elderly (34.5\%), and had a minimum-maximum age range of 31 to 83 years where the mean value was $58.46 \pm 10.72$. 
Table 1 The sociodemographic characteristics of respondents

\begin{tabular}{|c|c|c|c|c|c|}
\hline \multirow[b]{2}{*}{ Variable } & \multicolumn{2}{|c|}{ Frequency } & \multirow[b]{2}{*}{ Min } & \multirow[b]{2}{*}{ Max } & \multirow[b]{2}{*}{ Mean \pm SD } \\
\hline & $\mathbf{N}$ & $\%$ & & & \\
\hline Sex & & & 31 years & 83 years & $58.46 \pm 10.72$ \\
\hline Male & 44 & 52.4 & & & \\
\hline Female & 40 & 47.6 & & & \\
\hline \multicolumn{6}{|l|}{ Age } \\
\hline Adult (31-45 years) & 9 & 10.7 & & & \\
\hline Early elderly (46-55 years) & 29 & 34.5 & & & \\
\hline Late elderly (56-65 years) & 24 & 28.6 & & & \\
\hline Elderly (> 65 years) & 22 & 26.2 & & & \\
\hline \multicolumn{6}{|l|}{ Education } \\
\hline Uneducated & 8 & 9.5 & & & \\
\hline Elementary school (not passed yet) & 26 & 31 & & & \\
\hline Primary school (Passed) & 42 & 50 & & & \\
\hline Junior High School & 6 & 7.1 & & & \\
\hline Senior High School & 1 & 1.2 & & & \\
\hline Undergraduate & 1 & 1.2 & & & \\
\hline
\end{tabular}

Table 2 The Distribution of Related Factors in Drug Adherence

\begin{tabular}{|c|c|c|}
\hline \multirow[b]{2}{*}{ Variables } & \multicolumn{2}{|c|}{ Frequency } \\
\hline & $\mathbf{N}$ & $\%$ \\
\hline \multicolumn{3}{|l|}{ Drug Adherence } \\
\hline Good & 1 & 1.2 \\
\hline Moderate & 14 & 16.7 \\
\hline Poor & 69 & 82.1 \\
\hline \multicolumn{3}{|c|}{ Level of Knowledge } \\
\hline High & 20 & 23.8 \\
\hline Low & 64 & 76.2 \\
\hline \multicolumn{3}{|l|}{ Home Distance } \\
\hline Far & 28 & 33.3 \\
\hline Close & 56 & 66.7 \\
\hline \multicolumn{3}{|l|}{ Travel Time } \\
\hline$\leq 15$ minutes & 57 & 67.9 \\
\hline$\geq 15$ minutes & 27 & 32.1 \\
\hline \multicolumn{3}{|l|}{ Route Condition } \\
\hline Good & 63 & 75 \\
\hline Damaged & 21 & 25 \\
\hline \multicolumn{3}{|c|}{ Access Difficulties } \\
\hline Difficult & 22 & 26.2 \\
\hline Easy & 62 & 73.8 \\
\hline \multicolumn{3}{|l|}{ Family Support } \\
\hline Good & 35 & 41.7 \\
\hline Poor & 49 & 58.3 \\
\hline \multicolumn{3}{|c|}{ Role of Health Care Personnel } \\
\hline High & 80 & 95.2 \\
\hline Low & 4 & 4.8 \\
\hline \multicolumn{3}{|l|}{ Comorbidities } \\
\hline Yes & 13 & 15.5 \\
\hline No & 71 & 84.5 \\
\hline
\end{tabular}

Based on Table 2 it can be concluded that most of the respondents are still in poor drug adherence $(82.1 \%)$. It is followed by low level of knowledge (76.2\%), close home distance $(66.7 \%), \leq 15$ minutes for travel time (67.9\%), having good route condition $(75 \%)$, easy access $(73.8 \%)$, poor family support
(58.3\%), high role of healthcare personnel (95.2\%), and without comorbidities (84.5\%).

\section{Bivariate Analysis}

Based on Table 3, there are several related factors to the patient adherence in taking medication at Sukasada II Primary Health Care such as age, gender, education, knowledge, health service access, family support, the role of healthcare personnel, as well as comorbidities.

According to Table 3, the proportion of lack adherence tends to increase with age in hypertensive patients. It can be seen that good adherence to taking medication was predominant in the adult (31-45 years) (33.3\%) compared with elderly (> 65 years) $(9.1 \%)$. Also, the elderly population was most likely to have low adherence value (80.9\%) compared with adult (66.7\%)

Table 3 also indicates that the proportion of less medication adherence was higher in males (84.1\%) compared with female (80.0\%). Also, the percentage of less medication adherence tended to increase in the lower educated group by $82.9 \%$ compared with higher education population (75\%). However, the level of knowledge suggests different explanation where the proportion of patient adherence in taking medications that were perceived as less likely to increase in the high knowledge respondents (85\%) compared with the lower knowledge respondents (81.3\%).

The proportion of medication adherence is less likely to increase in respondents who have a close perception towards the health service access. About 85.7\% respondents who have poor adherence in taking medication are close to the health service access. Only $14.3 \%$ respondents are living close to the health service access have good medication adherence. This result also supports the travel time 
Table 3 Distribution of Drug Adherence Levels in the Hypertensive Patients at Sukasada II Primary Health Care by Related Factors

\begin{tabular}{|c|c|c|c|c|c|c|}
\hline \multirow[b]{3}{*}{ Related Factors } & \multicolumn{4}{|c|}{ Adherence } & & \\
\hline & \multicolumn{2}{|c|}{ Good } & \multicolumn{2}{|c|}{ Poor } & \multicolumn{2}{|c|}{ Total } \\
\hline & f & $\%$ & $\mathbf{f}$ & $\%$ & $f$ & $\%$ \\
\hline \multicolumn{7}{|l|}{ Age } \\
\hline Adult (31 - 45 years) & 3 & 33.3 & 6 & 66.7 & 9 & 100 \\
\hline Early elderly (46-55 years) & 3 & 10.3 & 26 & 89.7 & 29 & 100 \\
\hline Late elderly (56-65 years) & 7 & 29.2 & 17 & 70.8 & 24 & 100 \\
\hline Elderly (> 65 years) & 2 & 9.1 & 20 & 80.9 & 22 & 100 \\
\hline Total & 15 & 17.9 & 69 & 82.1 & 84 & 100 \\
\hline \multicolumn{7}{|l|}{ Gender } \\
\hline Male & 7 & 15.9 & 37 & 84.1 & 44 & 100 \\
\hline Female & 8 & 20.0 & 32 & 80.0 & 40 & 100 \\
\hline Total & 15 & 17.9 & 69 & 82.1 & 84 & 100 \\
\hline \multicolumn{7}{|l|}{ Education } \\
\hline Low & 13 & 17.1 & 63 & 82.9 & 76 & 100 \\
\hline High & 2 & 25 & 6 & 75.0 & 8 & 100 \\
\hline Total & 15 & 17.9 & 69 & 82.1 & 84 & 100 \\
\hline \multicolumn{7}{|l|}{ Knowledge } \\
\hline Low & 12 & 18.8 & 52 & 81.3 & 64 & 100 \\
\hline High & 3 & 15.0 & 17 & 85.0 & 20 & 100 \\
\hline Total & 15 & 17.9 & 69 & 82.1 & 84 & 100 \\
\hline \multicolumn{7}{|l|}{ Health Service Access } \\
\hline \multicolumn{7}{|l|}{ a. Distance Perception } \\
\hline Close & 8 & 14.3 & 48 & 85.7 & 56 & 100 \\
\hline Far & 7 & 25.0 & 21 & 75.0 & 28 & 100 \\
\hline Total & 15 & 17.9 & 69 & 82.1 & 84 & 100 \\
\hline \multicolumn{7}{|l|}{ b. Time Travel } \\
\hline$\leq 15$ minutes & 8 & 14.0 & 49 & 86.0 & 57 & 100 \\
\hline$\geq 15$ minutes & 7 & 25.9 & 20 & 74.1 & 27 & 100 \\
\hline Total & 15 & 17.9 & 69 & 82.1 & 84 & 100 \\
\hline \multicolumn{7}{|l|}{ c. Route Conditions } \\
\hline Good & 10 & 15.9 & 53 & 84.1 & 63 & 100 \\
\hline Damaged & 5 & 23.8 & 16 & 76.2 & 21 & 100 \\
\hline Total & 15 & 17.9 & 69 & 82.1 & 84 & 100 \\
\hline \multicolumn{7}{|l|}{ d. Access Difficulties } \\
\hline No & 10 & 16.1 & 52 & 83.9 & 62 & 100 \\
\hline Yes & 5 & 22.7 & 17 & 77.3 & 22 & 100 \\
\hline Total & 15 & 17.9 & 69 & 82.1 & 84 & 100 \\
\hline \multicolumn{7}{|l|}{ Family Support } \\
\hline Good & 6 & 17.1 & 29 & 82.9 & 35 & 100 \\
\hline Poor & 9 & 18.4 & 40 & 81.6 & 49 & 100 \\
\hline Total & 15 & 17.9 & 69 & 82.1 & 84 & 100 \\
\hline \multicolumn{7}{|l|}{ Role of Health Care Personnel } \\
\hline High & 0 & 0 & 4 & 100 & 4 & 100 \\
\hline Low & 15 & 18.8 & 65 & 81.2 & 80 & 100 \\
\hline Total & 15 & 17.9 & 69 & 82.1 & 84 & 100 \\
\hline \multicolumn{7}{|l|}{ Comorbidities } \\
\hline No & 12 & 16.9 & 59 & 83.1 & 71 & 100 \\
\hline Yes & 3 & 23.1 & 10 & 76.9 & 13 & 100 \\
\hline Total & 15 & 17.9 & 69 & 82.1 & 84 & 100 \\
\hline
\end{tabular}

to the health service where most of the poor medication adherence occur in the $\leq 15$ minutes $(86.0 \%)$ if compared with $\geq 15$ minutes (74.1\%).

The proportion of lack drug adherence tends to increase in respondents with good route conditions leading to health care settings. About $84.1 \%$ respondents have poor adherence in good route conditions compared with $76.2 \%$ of damaged route conditions. In addition, this study also found that the proportion of poor adherence tended to increase in respondents who had no difficulty access to the health services which accounted for $83.9 \%$. 
According to the family support, this result indicated that poor adherence to taking medication was predominant in the good family support group $(82.9 \%)$. However, it was a slight difference in the low-income family support group (81.6\%). Also, proportion lack of adherence tended more to the respondents stated that the role of health care personnel was still lacking. Finally, this study also found that the proportion of medication adherence was less likely in respondents who did not have comorbid disease accounted for $83.1 \%$ compared with respondents who had comorbidities.

\section{DISCUSSION}

The results of a study with 84 respondents at Sukasada II Public Health Care, Pancasari Sub-District, Buleleng regency showed that most patients were not adherence to taking medication about $82.1 \%$, while the respondents who had good medication adherence accounted for $17.9 \%$. The results are consistent with a study conducted by Morgado, et al. (2009) and Saleem, et al. (2011) who found that the prevalence of non-adherence patients taking the drug was higher than the adherence patients (64.7\%). ${ }^{10,11}$ Results of Basic Health Research in Indonesia (2013) also found similar results where from $28.1 \%$ prevalence of hypertension only $9.5 \%$ of them who consume drugs regularly. ${ }^{2}$ The factors that affect them include age, gender, level of education, knowledge, access to the health services, family support, the role of healthcare personnel, and comorbidities.

According to the age, the lack of adherence to taking hypertension medication tends to increase with age. The average age of non-adherence in taking hypertension medication is 59 years. It suggests that in elderly they are more likely to be disobedient to take medicine. Jaya (2009) in his study in Banten obtained results that age has a significant relationship with the adherence to hypertensive medication patients. ${ }^{12}$ Similar results were also found in studies conducted by Zyoud et al. (2013) in Palestine and Hareri et al. (2013) in Ethiopia where age was a factor that influences adherence due to changes in organ function as the increasing age. ${ }^{13,14}$ Patients with hypertension who are aged less than 60 years have high adherence, while elderly patients tend to be disobedient due to decreased memory that causes people to forget easily. ${ }^{13}$

Based on the sex of hypertensive patients, more males less likely to take hypertensive drugs than women. This result is consistent with a study conducted by Kebede A (2012) where sex is related to the medication adherence of hypertensive patients, although the impotence as a side effect of the antihypertensive medication. ${ }^{15}$ It is thought to be the reason why men tend to be non-adherence with the treatment of hypertension. This result was contrasted to the study conducted by Saepudin et al. (2010) which showed that males and females had the same adherence to taking hypertension medication. It is due to the absence of significant difference between the adherence female respondents (66\%) and adherence male respondents (61\%). Thus, both female and male respondents equally have the awareness to be adherence to the use of hypertension drugs.

This study also found that low adherence in taking medication tends to the respondents with less educated (82.9\%). A study conducted by Notoadmodjo (2010) stated that the level of education could influence the behavior of a person or society to health where changes in the level of public education allowed him to use health services better. ${ }^{9}$ It is also in accordance with the study conducted by Natsir (2003) on factors influencing the visit of community members in health service at the working area of Palanro Public Health Care, Baru District, stating that the educational level was very influential to the visit of the community in obtaining health services. Based on the results of an analytical study conducted by Exa Puspita (2016) showed that the last educational level was a risk factor for non-adherence medication hypertensive patients and people with low education risk 4 times disobedient in undergoing treatment of hypertension at Gunung Pati Public Health Care, Semarang. ${ }^{16}$

The result of the study shows that the respondents who have low and high knowledge level with less adherence accounted for $81.3 \%$ and $85,0 \%$ respectively. It is consistent with a study conducted by Abere Dessie Ambaw (2012) which shows that knowledge does not tend to the use of antihypertensive drugs. ${ }^{17} \mathrm{~A}$ study conducted by Nandang Tisna Ali Ami Jaya (2009) also found that respondent's knowledge of the hypertensive disease was good (64.1\%), sufficient (27.2\%), and low knowledge level $(8.7 \%)$. Most patient adherence in taking antihypertensive drugs is known to have less knowledge (0\%) will be more compliant rather than with good knowledge (52.2\%). The results of this study differ from Ekarini (2011) which showed that the efforts made by health workers indirectly able to increase the knowledge of hypertensive patients as well as motivate them to undergo regular treatment. Some of these efforts include by socializing the importance of daily therapy for hypertensive patients, health counseling about hypertension, and giving brochures about hypertension. 
According to the health service access, lack of medication adherence tends to increase in respondents who have close distance perception, travel time under 15 minutes, good route conditions, and have no difficulties accessing to health care. It shows that the average distance to the public health care of Sukasada II less than $5 \mathrm{~km}$ with adequate transportation facilities such as paved streets and good to pass still less adherence hypertensive patients taking medication. The results of this study similar with a study conducted by Annisa (2013) which stated that the respondents who easily to reach the health service settings and adherence to the treatment only 3 people (20\%) while 52 people (45.2\%) were not easy to reach the health service but adherence with the treatment. Thus, it can be said that people who are not easy to reach the health service seemed more adherence than those who quickly reach the health service.

Based on family support, the respondents with less adherence found more with good family support about $82.9 \%$. It is due to most of the respondents in this study were hypertensive elderly patients. The majority of respondents only live alone with their partner and do not live with children, family or close relatives. Pauline E Osamor (2015) found that social support factors that influence hypertension management adherence were social support from friends, while social support from families was less influential. ${ }^{18}$ His study found that most people talk and interact with their friends than family members. People with hypertension are more likely to discuss health issues with their friends than family members, so the family support is not as strong as the support of fellow patients with hypertension indirectly.

Considering the role of healthcare personnel, the low medication adherence tends to the respondents who say the lack of healthcare personnel role. Fajrin Violita (2015) noted that the respondents with a good healthcare role were found to be higher in adherence than the inadequate role of healthcare personnel. Support from good healthcare personnel is a reference to influence the respondent's adherence behavior. ${ }^{19}$

According to the comorbidities, the lack of medication adherence tended to the respondents who did not have any comorbid disease (83.1\%) compared with respondents who had comorbidities. A study conducted by Kenneth M. Shermock's in 2009 found that $65 \%$ of 200 respondents who have been studied did not meet adherence in taking medication were having major complication diseases such as stroke, atherosclerosis, renal disease, heart failure, and myocardial infarction.
While about $35 \%$ respondents with good adherence in taking medication had no chronic diseases.

\section{CONCLUSION}

This study results indicate that there is a tendency of patients with poor adherence to taking hypertension medication due to several things such as increasing age, high knowledge level, have a close perception of distance to the public health care, travel time under 15 minutes, good route conditions, no difficulties accessing to the health service, have good family support, lack of healthcare personnel role, and have no comorbidities.

\section{LIMITATIONS OF STUDY}

Limitations of this study are caused by the limits made by researchers in determining variables. Also, the data used in this study was the result of interviews using a questionnaire resulting in data weakness compared with a direct survey questionnaire of calculating the remaining medications for their adherence.

\section{REFERENCES}

1. Chobanian AV, Bakris GL, Black HR, Cushman WC, Green LA, et al. The Seventh Report of the Joint National Committee on Prevention, Detection, Evaluation, and Treatment of High Blood Pressure: the JNC 7 report. JAMA. 2003; 289(19): 2560-72.

2. Departemen Kesehatan RI. Pedoman Teknis Penemuan dan Tatalaksana Penyakit Hipertensi, Jakarta: Direktorat pengendalian penyakit tidak menular. 2013.

3. Madhur MS, Lob HE, McCann LA, et al. Interleukin 17 promotes angiotensin II-induced hypertension and vascular dysfunction. Hypertension. 2010 Feb. 55 (2):500-7.

4. WHO. Prevention of cardiovascular disease: guidelines for assessment and management of cardiovascular risk. Geneva, World Health Organization (WHO). 2007 Available at http://whqlibdoc.who.int/ publications/2007/9789241547178_eng.pdf. Accessed: February $7^{\text {th }} 18,2015$.

5. Palmer A and William, B. Simple Guide: Tekanan Darah Tinggi. Alih bahasa dr Elizabeth Yasmine. Editor Rina Astikawati, Amalia Safitri. Jakarta: Erlangga; 2007.

6. Burnier M, Schneider MP, Chioléro A, Stubi CL, Brunner HR. Electronic compliance monitoring in resistant hypertension: the basis for rational therapeutic decisions. J Hypertens. 2001; 19(2):335-41.

7. Noorfatmah S. Kepatuhan Pasien Yang Menderita Penyakit Kronis. 2012. Accessed on February $7^{\text {th }}, 2015$ (http://fpsi. mercubuana-yogya.ac.id/wpcontent/uploads/2012/06/ Noor-Kepatuhan...pdf)

8. Green LW et al. Health Education Planning: A Diagnostic Approach. Palo Alto, CA: Mayfield Publishing Co., 1980.

9. Notoatmodjo, Soekidjo. Metodologi Penelitian Kesehatan, Rineka Cipta; Jakarta. 2010.

10. Morgado M, Morgado S, Castanheira L, Verde I, CasteloBranco M. pharmacist interventions to enhance patient adherence to self-administered antihypertensive medication: a systematic review. International Journal of Cardiology. 2009; 137: S36-S37. 
11. Saleem F, Hassali MA, Shafie AA, Awad AG, Bashir S. Association between Knowledge and Drug Adherence in Patients with Hypertension in Quetta, Pakistan. Trop J Pharm Res. 2011; 10(2): 125-132.

12. Jaya N. Faktor-faktor yang berhubungan dengan tingkat kepatuhan pasien dalam minum obat antihipertensi di puskesmas pamulang kota tangerang selatan propinsi banten tahun 2009. 2009. Available at: http://perpus.fkik. uinjkt.ac.id/file_digital/Nandang\%20 Tisna.pdf. Accessed: February $7^{\text {th }} 2015$

13. Zyoud SH, Al-Jabi SW, Sweileh WM, Morisky DE. Relationship of treatment satisfaction to medication adherence: findings from a cross-sectional survey among hypertensive patients in Palestine. Health Qual Life Outcomes. 2013; 11:191.

14. Hareri, H.A., and Abebe, M. Assessments of Adherence to Hypertension Medications and Associated Factors among Patients Attending Tikur Anbessa Specialized Hospital Renal Unit, Addis Ababa, Ethiopia 2012. International Journal of Nursing Science. 2013; 3: 1-6.

15. Kebede A, Wabe NT. Medication adherence and its determinants among patients on concomitant tuberculosis and antiretroviral therapy in South west Ethiopia. N Am J Med Sci. 2012 Feb;4(2):67-71.
16. Puspita E. Faktor-Faktor yang Berhubungan dengan Kepatuhan Penderita Hipertensi dalam Menjalani Pengobatan (Studi Kasus di Puskesmas Gunungpati Kota Semarang). Universitas Negeri Semarang. 2016.

17. Ambaw AD, Alemie GA, Yohannes SM, Mengesha ZB. Adherence to antihypertensive treatment and associated factors among patients on follow up at University of Gondar Hospital, Northwest Ethiopia. BMC Public Health 2012; 12:282.

18. Osamor PE. Social support and management of hypertension in south-west Nigeria. Cardiovascular Journal of Africa. 2015; 26(1): 29-33.

19. Violita F, Thaha ILM, Dwinata I. Faktor yang Berhubungan dengan Kepatuhan Minum Obat Hipertensi di Wilayah Kerja Puskesmas Segeri. 2015. Available at http://repository.unhas.ac.id/handle/123456789/14096. Accessed February $10^{\text {th }} 2015$.

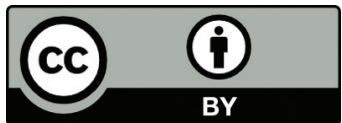

This work is licensed under a Creative Commons Attribution 